UDK 668.1

L. Seliverstova,

Doctor of Economic Sciences, Professor, Professor of Department of Finance, Kyiv National

University of Trade and Economics, Kyiv,

ORCID ID: 0000-0002-2231-0558

N. Tkachenko,

Doctor of Economic Sciences, Professor, Institute of Postgraduate Education,

Taras Shevchenko National University, Kyiv

ORCID ID: 0000-0001-6312-4586

DOI: $10.32702 / 2306-6814.2020 .3 .10$

\title{
TRENDS IN THE DEVELOPMENT OF THE UKRAINIAN INSURANCE MARKET
}

\author{
М. С. Селіверстова, \\ А. е. н., професор, професор кафедри фінансів, \\ Київський національний торговельно-економічний університет, м. Київ \\ Н. В. Ткаченко, \\ А. е. н., професор, заступник директора, \\ Інститут післядипломної освіти, Київський національний університет імені Тараса Шевченка, м. Київ
}

ТЕНАЕНЦІЇ РОЗВИТКУ СТРАХОВОГО РИНКУ УКРАЇНИ

In today's economic environment, the insurance market plays one of the leading roles in ensuring the protection of property interests of individuals and legal entities and long-term investment in the real sector of the Ukrainian economy. The insurance market is an extremely complex multilevel system consisting of a number of interconnected and interdependent subsystems such as: insurance products, tariffs, sales and demand generation, infrastructure and more. The formation of a developed insurance market in Ukraine will provide favorable conditions for market transformation and stable development of the national economy, the development of the world economy and international relations, which makes the research topic relevant.

The article considers and analyzes the current state of the Ukrainian insurance market and the main indicators of insurance activity for 2012-2019. It is determined that the reduction in the number of insurance companies is the result of the regulator's efforts to strengthen the market by removing players who do not meet the requirements of solvency and reliability. The key problems of the insurance market activity and problems that hinder its development are highlighted, the directions of its improvement and further development are suggested. The conducted research shows that the insurance market of Ukraine is an effective means of redistribution of funds that have previously been accumulated for further investment in the development of the country's economy.

The analysis of integration processes in the Ukrainian insurance market makes it possible to conclude that the degree of its development is insufficient and the need for further liberalization is aimed at facilitating integration into the global financial space. In Ukraine, as in the world insurance market, there is a process of increasing the capitalization of national insurers, the merger of insurance, banking and industrial capital. Liberalization of trade in insurance services facilitated the entry of Ukrainian insurers into foreign markets, but the presence of national insurance capital on them is negligible. Today, the Ukrainian insurance market is under development and has certain advantages and significant disadvantages: the growth rate of the insurance market is lagging behind the economic growth rate, and its share in the country's GDP is negligible. But the Ukrainian insurance market has a strong potential for development.

У сучасних умовах господарювання страховий ринок відіграє одну з провідних ролей у забезпеченні захисту майнових інтересів фізичних та юридичних осіб і довгостроковому інвесту- 
ванні у реальний сектор економіки України. Страховий ринок є надзвичайно складною багаторівневою системою, яка складається з низки взаємопов'язаних та взаємообумовлених підсистем, як-от: страхові продукти, тарифи, організація продажу і формування попиту, інфраструктура тощо. Формування розвинутого ринку страхових послуг в Україні забезпечить сприятливі умови для ринкової трансформації та стабільний розвиток національної економіки, розвиток світової економіки та міжнародних відносин, що й обумовлює актуальність теми дослідження.

У статті розглянуто та проаналізовано сучасний стан страхового ринку України та основні показники страхової діяльності за 2012-2019 роки. Визначено, що зменшення кількості страхових компаній є результатом роботи регулятора із зміцнення ринку шляхом виведення гравців, які не відповідають вимогам платоспроможності та надійності. Виділено ключові проблеми діяльності страхового ринку та проблеми, що стримують його розвиток, запропоновано напрями його вдосконалення та подальшого розвитку. Проведене наукове дослідження дає змогу констатувати, що страховий ринок України є ефективним засобом перерозподілу коштів, які раніше були накопичені для подальшого вкладання в розвиток економіки країни.

Аналіз інтеграційних процесів на страховому ринку України дозволяє зробити висновок про недостатній ступінь його розвитку та необхідність подальшої лібералізації, покликаної сприяти інтеграції у світовий фінансовий простір. В Україні, як і на світовому ринку страхування, має місце процес збільшення капіталізації національних страховиків, злиття страхового, банківського та промислового капіталів. Лібералізація торгівлі страховими послугами сприяла виходу українських страховиків на іноземні ринки, але присутність національного страхового капіталу на них незначна. На сьогодні страховий ринок України знаходиться на етапі розвитку та має певні переваги та значну кількість недоліків: темпи росту страхового ринку відстають від темпів росту економіки, а його частка в ВВП країни незначна. Але український страховий ринок має потужний потенціал для розвитку.

Key words: insurance, insurance company, insurance market, environmental factors, factors of the internal environment, life insurance, risk insurance types.

КлючоВі слоВа: страхуВання, страхоВа компанія, страхоВий ринок, фактори зоВнішнього середоВища, фактори Внутрішнього середоВища, страхуВання життя, ризикоВі Види страхуВання.

\section{SETTING OBJECTIVES}

Today, in an unstable economy, the role of insurance as a mechanism of accumulation of money supply and a source of long-term investments into the economy increases in the whole world, which in turn promotes financial stabilization, raising the quality of life of the population and ensuring the continuous production activity of enterprises and organizations. The insurance market of Ukraine is at the stage of gradual integration into the global financial market, therefore, the issue of modern development of the insurance services market and finding directions for its improvement is relevant and requires indepth study.

\section{ANALYSIS OF RESEARCH AND PUBLICATIONS}

The issues of the development of the theory and practice of the formation and functioning of the insurance market in their works were studied by such domestic scientists as Bazylevych V., Vasilik O., Grinchishin Ya., V. Diba, Klepikova O. [1], Muzyka O. [2], Prikazuk N., Ponomaryova O., Rotova T., Tkachenko N. [3], Seliverstova L. [4]. Despite the wide range of problems mentioned in the writings of scientists, the question of planning and prospects for the development of the Ukrainian insurance market requires the further research.

The purpose of the study is to analyze the trends of the insurance market development and to substantiate the directions of effective development of insurance companies.

\section{UNINVESTIGATED PARTS OF GENERAL MATTERS DEFINING}

The Ukrainian insurance industry remains in the process of its development and gradual integration into the world market, so the question of analyzing the trends of the insurance market development and finding directions for improving its activity is necessary and needs study indepth.

The research objective. As the result of the research, there will be the deep analysis of current trends in the insurance market of Ukraine and identified areas of improvement of its functioning.

\section{RESULTS}

The place of the insurance market in the financial system of Ukraine is due to the role of various financial institutions in financing insurance protection, as well as their significance as objects of placement of investment resources of insurance organizations and maintenance of insurance, investment, financial and other activities. The specificity of insurance determines the direct connection of the insurance market with the finances of enterprises and population, the banking system of the country, the state budget and other financial institutions, within which the insurance relations are implemented. In such a 


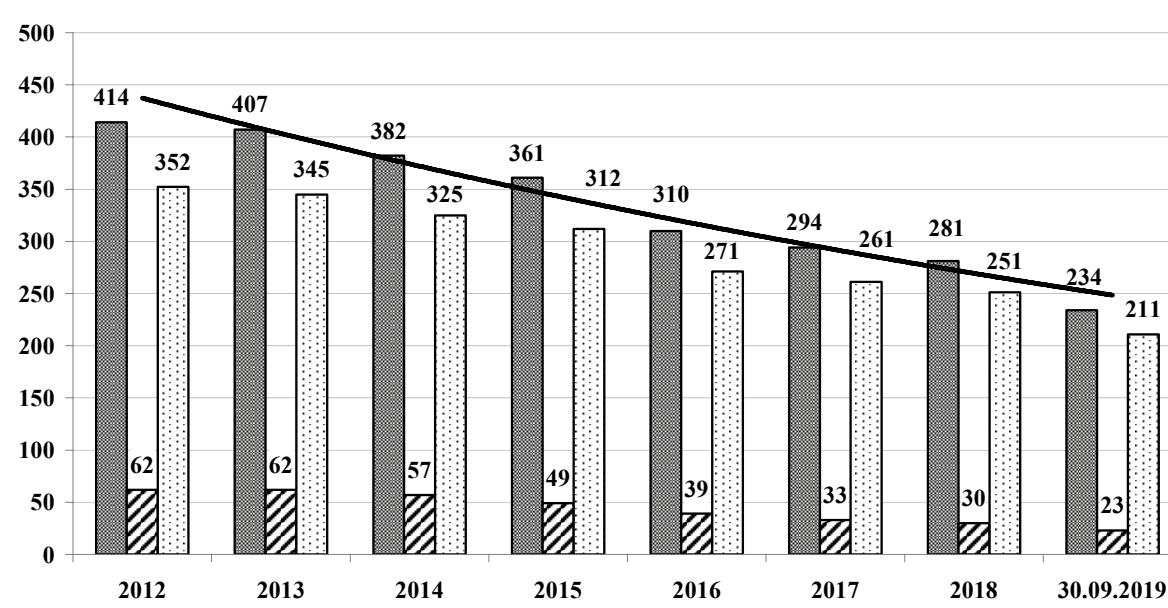

The total number of insurance companies

Ð Insurance companies "life"

๑Insurance companies "non-life"

\section{Pic. 1. Dynamics of the number of the insurance companies in the} domestic insurance market for 2012-2017 years [built on data 5] as an investment instrument, is not developing sufficiently but steadily and demonstrates a tendency for further growth.

The insurance market is the second in terms of capitalization among other non-bank financial markets. The total number of the insurance companies for 30.09.2019 was 234 , including the insurance companies for life insurance (IC "life") - 23 companies, other types of insurance (IC "non-life") - 211 companies [5].

The dynamics of the changes in the number of insurance companies in the domestic insurance market for $2012-2019$ years is shown in Pic. 1

Although the number of insurance companies tends to relationship, the relevant financial institutions act as insurers and consumers of insurance products. Specific relationships are formed between the insurance market and the state budget and the state extra-budgetary funds, which is associated with the organization of insurance [2, p. 248].

The insurance market is an important component of the financial market of the country and is closely connected with the industrial sphere and the level of welfare of the population. The positive changes in the economy, increasing the welfare of the population contribute to the activity of insurance companies, and the stable development of the latter, creates favorable conditions for improving the general state of the economy by investing their accumulated funds in various areas and industries [4, p. 65].

The modern insurance market in Ukraine is currently not the best time, since it is negatively affected by external and internal factors. Given the instability of the domestic economy and the military conflict in the country, insurance,

Table 1. The concentration of the insurance market during 2012-2016

\begin{tabular}{|l|l|l|l|l|l|l|l|l|}
\hline \multirow{2}{*}{$\begin{array}{c}\text { First } \\
\text { (Top) }\end{array}$} & \multicolumn{7}{|c|}{ Part at the insurance market «Life», \% } \\
\cline { 2 - 10 } & $\mathbf{2 0 1 2}$ & $\mathbf{2 0 1 3}$ & $\mathbf{2 0 1 4}$ & $\mathbf{2 0 1 5}$ & $\mathbf{2 0 1 6}$ & $\mathbf{2 0 1 7}$ & $\mathbf{2 0 1 8}$ & $\mathbf{2 0 1 9}$ \\
\hline Top 3 & 51.3 & 44,0 & 51.7 & 44.8 & 42.8 & 54.5 & 54.3 & 58.7 \\
\hline Top 10 & 87.1 & 90.4 & 90.9 & 91,2 & 87.9 & 95.9 & 96.9 & 96.7 \\
\hline Top 20 & 96.7 & 97,9 & 98.3 & 98.7 & 99.0 & 99.9 & 100.0 & 100.0 \\
\hline Top 50 & 100.0 & 100.0 & 100.0 & 100.0 & 100.0 & 100.0 & - & - \\
\hline Top 100 & - & - & - & - & - & - & - & - \\
\hline Top 200 & - & - & - & - & - & - & - & - \\
\hline $\begin{array}{l}\text { Totally at } \\
\text { the market }\end{array}$ & 100,0 & 100,0 & 100,0 & 100,0 & 100,0 & 100.0 & 100.0 & 100.0 \\
\hline & & & & & & & \\
\hline Top 3 & 13.7 & 9.9 & 13.5 & 15.6 & 14.7 & 21.3 & 15.0 & 15.3 \\
\hline Top 10 & 34.4 & 28.6 & 30.7 & 35.0 & 36.3 & 43.8 & 39.6 & 38.7 \\
\hline Top 20 & 53.6 & 46.8 & 50.3 & 53.8 & 60.3 & 62.9 & 61.9 & 59.9 \\
\hline Top 50 & 76.8 & 70.8 & 77.5 & 78.8 & 85.0 & 88 & 88.4 & 88.0 \\
\hline Top 100 & 92.1 & 84.3 & 92.1 & 93.4 & 96.1 & 97.6 & 97.9 & 98.1 \\
\hline Top 200 & 99.2 & 91.0 & 99.2 & 99.5 & 99.0 & 99.5 & 99.7 & 99.8 \\
\hline $\begin{array}{l}\text { Totally at } \\
\text { the market }\end{array}$ & 100.0 & 100.0 & 100.0 & 100.0 & 100.0 & 100.0 & 100.0 & 100.0 \\
\hline
\end{tabular}

* - for the 9 months of 2019.

The source: built on data [5]. decrease, the volume of gross insurance premiums and the amount of net insurance premiums testify to the effectiveness of the domestic insurance market development.

According to the National Commission of the regulation of state financial services markets, gross insurance premiums for the 9 months of 2019 increased by $16.3 \%$ to UAH 40.562 billion, of which individuals account for UAH 15.863 billion, which is $39.1 \%$, for legal entities persons - 24.699 billion UAH $(60.9 \%)$. Thus, net insurance premiums for the 9 months of 2019 increased by $18.8 \%$ to UAH 30.149 billion, which is $74.3 \%$ of gross premiums.

For risk insurance, UAH 37.268 billion was received, representing $91.9 \%$ of the total premiums, and life insurance - UAH 3.294 billion or $8.1 \%$ of the total premiums.

The increase in gross premiums was observed to the following types of insurance: financial risk insurance $(+43.7 \%)$, property insurance $(+10.8 \%)$, fire and risks insurance $(+15.1 \%)$, car insurance $(+17.2 \%)$, life insurance $(+20,2 \%)$, health insurance $(+39.3 \%)$, accident insurance $(+12 \%)$ and air insurance $(+19.4 \%)$. At the same time, the decline in net insurance premiums was observed in the following types of insurance: liability insurance $-(-6,7 \%)$, cargo and luggage insurance $(-2,7 \%)$, credit insurance $(-13,7)$.

Consequently, the negative characterization of the trend of reduction of insurers is incorrect, since: firstly, the practice of 2004-2007, the characteristic feature of which was to increase the profitability of insurance companies on an extensive basis, was evidenced by the fact that the quantitative growth of the insurance portfolio does not lead to a qualitative change. The rate for the "scale effect" is not justified, as a result of which the effectiveness of Ukrainian insurers does not reach the efficiency that is characterized by foreign insurance companies. Secondly, the insurance market has long overdue the issue of consolidation 
of insurers, since the concentration of insurance market for the receipt of gross insurance premiums of the first 20 insurers, for example, at the end of 2018 , accounted for $100.0 \%$ of insurance "life", and insurance "non - life" $61.9 \%$. This state of affairs is characteristic not only for 2018; it is typical for the insurance market of Ukraine during the investigated period (Table 1).

Thus, despite the large number of companies, in fact, in the insurance market, the bulk of gross insurance premiums - 98.1\% - are accumulated by 100 non-life ICs (47.4\% of all non-life ICs) and $96.7 \%-10$ Life Insurance Company (43.5\% of all Life Insurance Company).

For the life insurance market, the Herfindahl-Hirschman Index (HHI) was 1540.28 (for the 9 months of 2018 1445.23 ), for the risk insurance market it was 273.79 (for the 9 months of $2018-248.57)$. As a whole for the insurance market, the Herfindahl-Hirschman index was 210.90 (for 9 months of $2018-219.96$ ). The data indicate that over the 9 months of 2019, there was a significant level of competition in the insurance market other than life insurance ( $\mathrm{HHI} 3$ times less than 1000), while there was moderate monopolization in the life insurance market.

TOP-10 of the largest insurers for bonuses for 9 months of 2017 is given in Table 2.

The size of gross insurance premiums for 6 months of 2019 increased by $16.5 \%$ and amounted to 27.3 billion $\mathrm{UAH}$, including 25.2 billion UAH (92.3\%) for risk insurance, and 2.1 billion UAH (7.7\%) for life insurance. Net insurance payments increased by $20.1 \%$ and amounted to 20.1 billion UAH (73.7\% of Gross premiums).

The gross insurance payments for the first half of 2019 amounted to UAH 6.67 billion ( $\$ 265.8$ million), includes the risk insurance - UAH 6.38 billion. (95.7\%). Gross payments increased by $9.8 \%$, net insurance payments increased by $11.3 \%$ to UAH 6.53 billion. The gross payments amounted to $24.4 \%$ as of 30.06 .2019 . The net payout rate was $32.4 \%$.

TOP-10 of the largest risk companies for 9 months of 2017 are shown in Pic. 2.

The number of concluded insurance contracts decreased by $2.4 \%$. Insurance reserves increased by 5043 million UAH. (+21\%) comparing with the same date in 2018 , while technical reserves increased by $\mathrm{UAH}$ 3,720 million. $(+24 \%)$.

The total assets of Ukrainian insurance companies as of June 30, 2019 amounted to 65.3 billion $\mathrm{UAH}$, which is $14 \%$ more. The amount of assets defined by Art. 31 of the Law of Ukraine "On Insurance", increased by $17.8 \%$ to 42.7 biIlion UAH.

The total number of insurers in the 1st half of 2019 was 249 companies: 26 life insurance companies and 223 risk insurance companies (the number of companies decreased by 42 or $14.4 \%$ over the year). However, in fact, in the insurance market, the main share of gross premiums of $98.2 \%$ is accumulated by 100 risk insurers.

Gross insurance payments increased over the 9 months of 2019 by $12.5 \%$ to
Table 2. TOP-10 of the largest insurers for bonuses for 6 months of 2019, (ths UAH)

\begin{tabular}{|l|l|l|l|}
\hline \multicolumn{1}{|c|}{ Insurance companies } & \multicolumn{1}{|c|}{$\begin{array}{c}\text { № } \\
\text { In rating }\end{array}$} & $\begin{array}{c}\text { Gross } \\
\text { premiums, } \\
\text { ths UAH }\end{array}$ & $\begin{array}{c}\text { Growth, } \\
\text { \% }\end{array}$ \\
\hline ARX & $\mathbf{1}$ & 1123063 & $+22,66$ \\
\hline UNIKA & $\mathbf{2}$ & 1110201 & $-2,61$ \\
\hline ARSENAL INSURANCE & $\mathbf{3}$ & 1029025 & $+14,85$ \\
\hline USG \& GLOBUS & $\mathbf{4}$ & 921950 & $+107,94$ \\
\hline TAS SG & $\mathbf{5}$ & 856811 & $+35,77$ \\
\hline PZU UKRAINE & $\mathbf{6}$ & 831817 & $+24,24$ \\
\hline INGO UKRAINE & $\mathbf{7}$ & 748968 & $+35,45$ \\
\hline ALFA INSURANCE & $\mathbf{8}$ & 517485 & $+47,51$ \\
\hline UNIVERSAL & $\mathbf{9}$ & 490311 & $+17,40$ \\
\hline ASKA & $\mathbf{1 0}$ & 487236 & $+44,38$ \\
\hline
\end{tabular}

UAH 9.846 billion. The level of gross payments decreased from $25.1 \%$ to $24.3 \%$. In January - September 2019 , insurers paid UAH 9.624 billion in net insurance payments (13.7\% more). The level of net payments decreased from $33.3 \%$ to $31.9 \%$.

A high level of gross insurance payments is observed in car insurance - an increase of $14 \%$, medical insurance - by $28.4 \%$, financial risks by $5.3 \%$, medical expenses by $18.8 \%$.

The above data suggests that the modern insurance market is developing, but there are still many problems that require urgent solutions. Thus, the external factors of inhibition of the development of the insurance market should be considered: the imperfection of the regulatory framework; the low demand of individuals and legal entities for the range of insurance services, which is associated with low solvency of potential insurers; the lack of reliable investment programs, as well as real financial mechanisms for long-term placement of insurance reserves; the information opacity of insurance companies; the distrust of the population to any kinds of investments; the political instability; the inflation growth; the insufficient development of the stock market; the insufficient level of information about the state and the possibilities of the insurance market; the lack of reliable long-term instruments, as well as guarantees of preservation and return of invested funds; the impossibility (in accordance

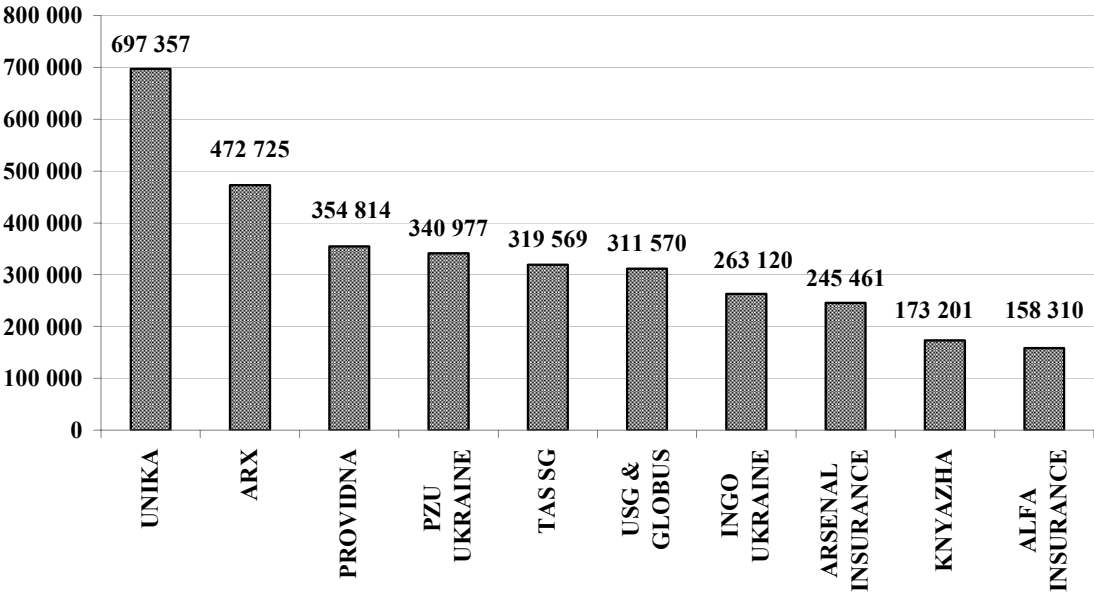

Insurance payments, ths.UAH

Pic. 2. Insurance payments of TOP-10 of the largest risky companies of Ukraine for the 6 months of 2019 (ths. UAH) [based on data 5] 
with the current legislation) the storage of insurance reserves in freely convertible currency, which leads to the impairment of insurance reserves, due to the instability of the national currency; the lack of qualitative and timely statistical information and the lack of detailed informationanalytical materials on the state and problems of the formation of the insurance market in Ukraine.

The internal factors of the inhibitory impact on the development of insurance should include: the insufficient range of insurance services provided to customers; the low level of diversification of services; the unsatisfactory condition of service of the insured; the lack of manufacturability of insurance operations; the lack of effective risk management systems; the imperfection of the system of informational and analytical support of insurance activity; the low financial reliability and solvency of insurers; the inefficiency of the state regulation of insurance in Ukraine; the lack of well-qualified insurance experts.

Despite the above problems, the potential for development of the Ukrainian insurance market is very high. The positive trends in the development of the insurance services market include: the strengthening of the insurance market by means of withdrawal of players the insurance companies that do not meet the requirements of solvency and reliability of insurers; the assets of the insurance companies remaining on the insurance market of Ukraine comply with the quality and diversification requirements established by the National Financial Services Commission; the significant increase in the level of the insurance culture among managers of enterprises and among the population.

Ukraine is lagging behind in the process of bringing the regulation of the insurance activities in line with world standards [6]. The development of the insurance market as an integral part of the financial market of Ukraine, its further dynamic development, volumes and directions of economic entities financing will depend on expanding the range of insurance services, increasing their competitiveness, improving the regulatory framework in terms of taxation and increasing requirements to the order the creation of insurance companies, ensuring the optimal structure of the relationship between compulsory and voluntary insurance, attracting the insurance market to the solution of the problems of social insurance, further integration into international structures, involving the insurance market to address critical issues of economic development.

\section{CONCLUSION}

The stage of political and economic instability in Ukraine has a significant impact on the development of both the insurance companies separately and the insurance market as a whole. The decrease in the level of solvency of the population and insurers' confidence in recent years has led to a significant decrease in the demand of insurance services. Therefore, today insurers face a difficult task of increasing assortment, volume and quality of insurance services, raising the level of capitalization and financial reliability of insurance companies, gaining trust in legal entities and individuals. Following the abovementioned measures aimed at overcoming the crisis trends, the domestic economy will be able to attract the significant investment resources, strengthen the effectiveness of state supervision of insurance activities, and create the structural framework for the development of various types of insurance. One of the important internal factors in the development of insurance business may be process of underwriting of a separate insurance company that is effectively built. The application of this approach will ensure the profitability and financial stability of the insurance companies through a thorough analysis and selection of risks for their acceptance for insurance.

\section{Література:}

1. Клепікова О.А. (2013) Моделювання маркетингової стратегії страхової компанії. Вісник Київського національного університету ім. Т.Г. Шевченка. Економіка. № 6 (147). С. 55-60.

2. Музика О.М. (2008) Стан та тенденції розвитку страхового ринку України. Збірник науково-технічних праць НЛУУ. Львів. 2008. С. 246-255.

3. Ткаченко Н.В. (2016) Вплив глобалізаційних процесів на розвиток фрінансових посередників. Наукові записки Національного університету "Острозька академія". Серія "Економіка": збірник наукових праць. (Вип. 26). pp. 81-88. URL: http://www.outlaw.com/ en /articles /2016/ january/insurerstechs tartupinvestmentindicatesgrowingimportanceofdigitaltechnologyinthe industrysaysexpert

4. Seliverstova L. S. (2017) Current trends in insurance market in Ukraine. Науковий вісник Полісся. № 2 (10). 4. 1. C. $63-69$.

5. Інтернет журнал зі страхування та перестраховання. URL: https://forinsurer.com

6. Адаменко І.П., Селіверстова Л.С. (2018) Особливості розвитку фрінансового ринку України. Інвестиції: практика та досвід. № 9. С. 13-17.

\section{References:}

1. Klepikova, O. A. (2013), "Simulation of insurance company marketing strategy", Visnyk Kyivs'koho natsional'noho universytetu im. T.H. Shevchenka. Ekonomika, vol. 6 (147), pp. 55-60.

2. Muzyka, O.M. (2008), "State and tendencies of development of the insurance market of Ukraine", Zbirnyk naukovo-tekhnichnykh prats' NLUU, pp. 246-255.

3. Tkachenko, N.V. (2016), "The impact of globalization processes on the development of financial intermediaries", Naukovi zapysky Natsional'noho universytetu "Ostroz'ka akademiia". Seriia "Ekonomika": zbirnyk naukovykh prats', vol. 26, pp. 81-88, available at: http://vvv.outlav.tsom/ en/artitsles/2016/ianuary/insurerstechstartupinvestmentinditsatesgrovingimportantseofdigitaltechnologyintheindustrysaysekhpert (Accessed 15 Jan 2020).

4. Seliverstova, L. S. (2017), "Current trends in insurance market in Ukraine", Naukovyj visnyk Polissia, vol. 2 (10), no. 1, pp. 63-69.

5. Forynshurer (2020), available at: https://forinsurer.com (Accessed 15 Jan 2020).

6. Adamenko, I.P. and Seliverstova, L.S. (2018), "Features of development of the financial market of Ukraine", Investytsii: praktyka ta dosvid, vol. 9, pp. 13-17. Стаття надійшла до редакиії 03.02.2020 p. 